\title{
Human-Device Interface Issue
}

National Cancer Institute

\section{Source}

National Cancer Institute. Human-Device Interface Issue. NCI Thesaurus. Code C76121.

Problem associated with an act or omission of an act that has a different result than that intended by the manufacturer or expected by the operator. 